\title{
Purification and Characterization of Streptomyces Canarius L- Glutaminase and its Anticancer Activity
}

\section{F.M. Reda*}

Department of Botany and Microbiology, Faculty of Science, Zagazig University, 44519, Zagazig, Egypt.

\begin{abstract}
T -GLUTAMINASE produced by Streptomyces canarius FR (KC460654) was purified to homogeneity with an apparent molecular mass of $44 \mathrm{kDa}$. The purified enzyme was 17.9 fold with a final specific activity $132.2 \mathrm{U} / \mathrm{mg}$ protein and $28 \%$ yield recovery. The purified L- glutaminase showed a maximal activity against Lglutamine when incubated at $\mathrm{pH} 8.0$ and $40^{\circ} \mathrm{C}$ for $30 \mathrm{~min}$. The enzyme maintained its stability at wide $\mathrm{pH}$ range for 5.0-11.0 and is thermally stable up to $60^{\circ} \mathrm{C}$ with $\mathrm{Tm}$ value $57.5^{\circ} \mathrm{C}$. The enzyme had high affinity and catalytic activity for L- glutamine ( Km $2.4 \mathrm{mM}$, Vmax 28.1 $\mathrm{U} / \mathrm{mg} / \mathrm{min}$ ), followed by L- asparagine and L-aspartic acid. In vivo, the purified enzyme showed no obvious changes in liver and kidney functions. Also, it has a normal effect in all hematological parameters except slight effect on RBCs and levels of platelets as shown after 10 days of rabbit's injection with purified enzyme. Interestingly, it showed slight effect on the tested renal and liver tissues comparing with negative control. The anticancer activity of the purified enzyme was determined against five types of human cancer cell lines using MTT assay in vitro. The tested enzyme had a high efficiency against Hep-G2 cell $\left(\mathrm{IC}_{50}, 6.8 \mu \mathrm{g} / \mathrm{ml}\right)$ and HeLa cells $\left(\mathrm{IC}_{50}, 8.3 \mu \mathrm{g} / \mathrm{ml}\right)$, while the growth of MCF-7 cells was not affected. On the other hand, the tested enzyme had a moderate cytotoxic effect against HCT-116 cell $\left(\mathrm{IC}_{50}, 64.7 \mu \mathrm{g} / \mathrm{ml}\right)$ and RAW 264.7 cell $\left(\mathrm{IC}_{50}, 59.3 \mu \mathrm{g} / \mathrm{ml}\right)$.
\end{abstract}

Keywords: L-glutaminase, Anti-cancer, Cytotoxicity, MTT assay.

L-glutaminases (L-glutamine amidohydrolase E.C 3.5.1.2) are ubiquitous in the biological world and organisms ranging from bacteria to human beings have the enzyme (Chantawannakul et al., 2003). The enzyme catalyzes the deamidation of L-glutamine to L-glutamic acid and ammonia (Roberts et al.,1970). Lglutaminase has been received significant attention since it was reported extensively as antileukemic agent and use in food industries imparting the flavor and aroma to the foods (Kyoko et al., 2004; Robert et al., 2001).

Since the discovery of its anti-tumor properties, L-glutaminases have been in prime focus and microbial sources of the enzyme are sought. Where, high rate of glutamine consumption is a characteristic nature of some types of cancerous cells

*Corresponding author: E-mail: afm67@yahoo.com, Fifi.reda133@yahoo.com 
(Lazarus and Panasci 1986). Based on this character experimental therapies have been developed to deprive L-glutamine to tumor cells (Iyer and Singhal 2008). Tumor growth regulation can be achieved by inhibition of both protein and nucleic biosynthesis in the cancerous cells due to the lack of availability of any component of these acid macromolecules (Tanaka et al.,1988). Inhibition of the tumor cell uptake of glutamine is one of the possible ways to stop the growth and this is the best accomplished by the use of L-glutaminase, which breaks down Lglutamine. This in fact, results in a selective starvation of the tumor cells because unlike normal cells they lack properly functioning glutamine biosynthetic machinery (Tanaka et al.,1988 and Dang 2010). Warrell et al. (1982) used the Lglutaminase against adult leukemia. One of the major problems encountered in the treatment with microbial L-glutaminases is the development of immune responses against the enzyme.

Microbial therapeutic enzymes have a broad variety of specific uses: as oncolytics, thrombolytics or anticoagulant and largely as anticancer (Sabu 2003; Sabu et al., 2005). Although microorganisms are potential sources of therapeutic enzymes, utilization of such enzymes for therapeutic purposes is limited because of their incompatibility with the human body. But there is an increased focus on utilization of microbial enzymes because of economic feasibility (Sabu 2003).

Streptomycetes have attracted much attention because of their ability to make secondary metabolites that have a wide range of bioactivities and thereby may find use as antibiotics, immunosuppressants and anti-canceragents (Kieser et al., 2000). They are soil-inhabiting Gram-positive bacteria with a high $\mathrm{G}+\mathrm{C}$ content and it belonging to the order of Actinomycetales (Garrity 2002). Wakayama et al. (2005) observed that the L-glutaminase produced from actinomycetes has a good salt tolerance; and thermostable (Masayukr et al., 2007). So for only few marine actinomycetes have been explored for their L-glutaminase production (Krishnakumar et al., 2011).

The enzyme is produced throughout the world by both submerged and solidstate cultures. Extracellular glutaminases from actinomycetes are more advantageous than intracellular ones, since they can be produced abundantly in the culture broth under normal conditions, and purified economically. In the light of the previous fact this study aimed to extract and characterize of the purified Lglutaminase from Streptomyces canarius FR cultures. Biochemical, kinetics and in vivo anti-carcenogenic properties of L-glutaminase will be also studied.

\section{Material and Methods}

Identification of L-glutaminase producing actinomycete strain

Streptomyces canarius FR isolated from tombs of New Kingdom, Tell Basta, Zagazig, Sharkyia Governorate, Egypt was identified by various parameters such as colony morphology, spore arrangement, physiologically and biochemically according to identification keys (Kämpfer 2006). The identification was molecularly confirmed by the analysis of $16 \mathrm{~S}$ rRNA gene sequence. The $16 \mathrm{~S}$ Egypt. J. Bot., 54, No. 1 (2014) 
rRNA gene sequence, which have been determined in the present study, were deposited at NCBI web server (http://www. ncbi.nlm.nih. gov/ Genbank/ update. html) with the following accession no KC748492. Sequence analysis and comparison to published sequences made using the Basic Local Alignment Search Tool (BLAST) program (http://blast.ncbi.nlm.nih.gov/Blast.cg) (Altschul et al., 1997).

The strain was preliminary tested for L-glutaminase production by streaking on minimal glutamine agar medium (MGA) plates. Components of MGA (g/L) include: $\mathrm{KCl} 0.5 ; \mathrm{MgSO}_{4} \cdot 7 \mathrm{H}_{2} \mathrm{O} 0.5 ; \mathrm{KH}_{2} \mathrm{PO}_{4} 1.0 ; \mathrm{FeSO}_{4} \cdot 7 \mathrm{H}_{2} \mathrm{O} 0.1 ; \mathrm{ZnSO}_{4} \cdot 7 \mathrm{H}_{2} \mathrm{O}$ 1.0; glutamine 5 and phenol red 0.012 . The plates were incubated at $30^{\circ} \mathrm{C}$ for 5 days. Formation of pink zones around the microbial growth indicated the positive reaction (Balagurunathan and Subramanian 1993, Balagurunathan et al., 2010).

Optimization of culture conditions for L-glutaminase production

Streptomyces canarius FR was cultivated in L-glutaminase production modified Czapek's medium contained $(\mathrm{g} / \mathrm{L})$ : L-glutamine 10; D-glucose 5; $\mathrm{MgSO}_{4} \cdot 7 \mathrm{H}_{2} \mathrm{O} 0.5 ; \mathrm{KCl} 0.05 ; \mathrm{KH}_{2} \mathrm{PO}_{4}$ 1.0. Enzyme production was tested under different cultured conditions; different incubation periods (0-8 days); different temperatures $\left(25-55^{\circ} \mathrm{C}\right)$; different $\mathrm{pH}$-values $(\mathrm{pH} 4-10)$ under shaking and static conditions. The culture was harvested and centrifuged at 10,000 rpm for $30 \mathrm{~min}$; the obtained cell free filtrate was used as crude enzyme according to Dura et al. (2002).

Activity assay and Protein determination of enzyme

The activity of glutaminase enzyme is determined by estimating the amount of $\mathrm{NH}_{3}$ liberated from glutamine (Borek et al., 2004). Protein concentration was determined by Lowery et al. (1951) using bovine serum albumin (Sigma chemical Co.) as a standard.

\section{L- glutaminase purification}

Two liters from the nutritionally optimized submerged 5 days culture of $S$. canarius FR growing in L-glutaminase producing medium was prepared. The precipitated protein was collected by centrifugation at $10.000 \mathrm{rpm}$ at $4{ }^{\circ} \mathrm{C}$ and dissolved in a minimum volume of phosphate buffer $(0.01 \mathrm{M}, \mathrm{pH} 8.0)$ (Sabu et al., 2005). L- glutaminase was fractionated by salting out (50-80\% ammonium sulphate saturation). The collected precipitate was dissolved in phosphate buffer (0.01 M, pH 8.0) and then dialyzed against the same buffer for $24 \mathrm{hr}$ at $4^{\circ} \mathrm{C}$ with continuous stirring and occasional changes of the buffers. The dialyzate was fractionated by Sephadex G100 gel-filtration chromatography. After column equilibration the enzyme was eluted by phosphate buffer $(0.1 \mathrm{M}, \mathrm{pH} 8.0)$ with 0.001 M EDTA. The activity, homogeneity (SDS-PAGE) and protein contents of the fractions were determined as above. The most active homogenous fractions were gathered and loaded to pre-equilibrated column of Sephadex G50 using the same buffer for elution. For each fraction activity was assessed as above. The 
most active fractions were pooled and concentrated by dialysis against buffer (Nagendra Prabhu, 1997).

SDS-PAGE Analysis

The homogeneity and molecular weight of L- glutaminase from culture of $S$. canarius was carried out using SDS-PAGE according to Lammeli (1970). PageRuler Unstained Protein Ladder, Fermentas marker was used.

\section{Biochemical Properties of the purified L-glutaminase enzyme}

The biochemical properties of purified $S$. canarius L- glutaminase as optimum $\mathrm{pH}, \mathrm{pH}$ stability, reaction temperature, thermal stability salt tolerance, metal ions and substrate specificity enzyme were determined as Amena et al. (2010) and Sabu et al. (2005).

The thermal stability of enzyme was studied after preincubation of the enzyme at various temperatures $\left(50-80^{\circ} \mathrm{C}\right)$ using $0.1 \mathrm{M}$ phosphate buffer $(\mathrm{pH} 8.0)$ for different time (10-90 $\mathrm{min})$. The enzyme relative activity was determined after the incubation of reaction mixture at $37^{\circ} \mathrm{C}$ for $30 \mathrm{~min}$. The thermal inactivation rate ( $\mathrm{Kr} \mathrm{min}$ ) can be described by the first-order kinetic model (Whitaker, 1972); Ln $\left(A_{t} / A_{o}\right) k_{t} T$, where $A_{o}$ and $A_{t}$ are the specific activity zero and time. $T_{1 / 2}$ (time at which the enzyme loss $50 \%$ of its activity) was calculated from the linear equation for each temperature. The temperature at which the enzyme loss $50 \%$ of its activity (Tm) was calculated from the linear equation of different preincubation temperature at $60 \mathrm{~min}$.

Stability of L-glutaminase was examined after pre-incubation of the enzyme for $2 \mathrm{hr}$ at different $\mathrm{pH}$ values ranging from 4.0-11.0. Acetate $(0.2 \mathrm{M})$, phosphate $(0.2 \mathrm{M})$ and glycine- $\mathrm{NaOH}$ buffers were used to covering $\mathrm{pH}$ range (4-5), (6-8) and $(9-11)$ respectively. After adding glutamine $(40 \mathrm{mM})$ the reaction mixture was incubated at $37^{\circ} \mathrm{C}$ for $30 \mathrm{~min}$. The activity of the enzyme was determined for each $\mathrm{pH}$.

To assay the metal ions effect, the purified enzyme was pre-incubated with each metal ion separately for $30 \mathrm{~min}$ before adding glutamine $(40 \mathrm{mM})$. The enzyme relative activity was determined immediately after incubation at $37^{\circ} \mathrm{C}$ for $30 \mathrm{~min}$.

The kinetic parameters of L-glutaminase as Vmax, $\mathrm{Km}$ and Kcat were estimated using different concentrations of glutamine, asparagine and aspartic acid, separately (10-100mM). Michaelis-Mentel constant $(\mathrm{Km})$ and maximum velocity (Vmax) were calculated from Lineweaver-Burk plot. Catalytic efficiency (Kcat) was expressed by the specific activity per mol enzyme.

\section{Cytotoxicity of L- glutaminase}

Cytotoxic effect of the purified enzyme was evaluated using five New Zealand rabbits groups each contained five one. Rabbits were intravenous (i.v.)

Egypt. J. Bot., 54, No. 1 (2014) 
injected by $1 \mathrm{ml}$ of three successive doses of L- glutaminase $(132.2 \mathrm{U} / \mathrm{mg}$ protein $/ 1.5 \pm 0.1 \mathrm{Kg}$ ) during two weeks. Blood samples were collected after 10 , 25, 40 and 50 day of the last injection. Control sera (zero time) without enzyme injection were used. Plasma were prepared and stored at $-20^{\circ} \mathrm{C}$. To evaluate the biological effects of the enzyme on blood chemistry of treated rabbits, various hematological parameters as RBC, WBC, platelets, hemoglobin and biochemical parameters as ALT, AST, GGT, total protein, albumin, cholesterol, glucose and creatinine were determined as described by Birt (1967) and Reitman and Frankel (1957). Hemolytic activity of the purified L-glutaminase was evaluated using a blood agar assay (Tay et al., 1995).

\section{Histopathological characterization}

For histological studies, small portion of liver and kidney of treated and nontreated rabbits after 50 days of the last injection were removed and fixed overnight in $10 \%$ formalin according to Roy and Maity (2007).

Anticancer activity of $S$. canarius L-glutaminase against various cell lines In Vitro

Human hepatocarcinoma cell line (HepG2), Human breast adenocarcinoma cell line (MCF-7), human colorectal carcinoma cells (HCT-116), Human cervical carcinoma cell line (HeLa) and Raw murine macrophage (RAW 264.7) purchased from ATCC, USA were used.

Anticancer efficiency of tested enzyme was measured against HepG2, MCF7, HCT-116, HeLa and RAW 264.7 cells using the MTT Cell Viability Assay (Hansen et al., 1989). \% Cell viability = O.D of treated cells / O.D of control cells X 100 .

The $\mathrm{IC}_{50}$ value was expressed by the concentration of enzyme required to inhibit $50 \%$ of initial growth of tumor cells. $\mathrm{IC}_{50}$ for L-glutaminase was determined against five human cell lines, using sigmoidal dose response curvefitting models (Graphpad Prizm Software, version 3).

Statistical analyses

All data were the mean of three replicates \pm SD (standard deviation). ANOVA test (one way) and t- test were calculated in all cases, significance was measured by LSD at $\mathrm{p}<0.05$ using SPSS program version 10.0 (Salvatore and Reagle, 2001).

\section{Results and Discussion}

\section{Identification of L-glutaminase producing strain}

Streptomyces canarius FR strain was identified by studying their morphological and biochemical characterization according to identification keys. PCR amplification of $16 \mathrm{~S}$ rDNA gene confirmed the identity $(98 \%)$ of selected potent strain as $S$. canarius FR. The partial nucleotide sequence of amplified gene was submitted in GenBank (http://www. ncbi. nlm. nih. gov/ 
GenBank/update.htm) under accession number KC748492. Our results derived from the sequence analysis of the $16 \mathrm{~S}$ rRNA gene show a $\mathrm{G}+\mathrm{C}$ content of 58.9 mol \% which is in good agreement with the data published for Streptomyces by Kannan and Vincent (2011). The tested strain was characterized by formation of a pink zone around colonies using MGA medium due to breakdown of amide bond in L-glutamine and ammonia liberation (Ranjekar and Sridhar, 2002).

Optimization of L-glutaminase production by submerged fermentation

The enzyme was produced from the submerged fermented culture of $S$. canarius under optimum conditions at $30^{\circ} \mathrm{C}$ for 5 days and $\mathrm{pH} 7.5$ under shaking condition at $120 \mathrm{rpm}$ (Data was not shown). Dura et al. (2002) and Sabu (2003) stated that submerged fermentation was the routinely used methods for L-glutaminase production from various microorganisms. Krishnakumar et al. (2011) showed that production of L-glutaminase from Streptomyces sp. SBU1 was at $30^{\circ} \mathrm{C}$ after $96 \mathrm{hr}$ of incubation and initial $\mathrm{pH}$ 9.0. Balagurunathan et al. (2010) stated that, the optimum conditions for marine Streptomyces olivochromogenes L-glutaminase production were determined at $\mathrm{pH} 7$, temperature $30^{\circ} \mathrm{C}$ and $3.5 \%$ salinity for 5 days under shaking condition at $120 \mathrm{rpm}$.

\section{Purification of L-glutaminase}

The enzyme was purified from 5 days $S$. canarius culture to assess their yield and purity. The crude enzyme was undergoes fractional precipitation by salting out (50-80\% ammonium sulfate). The enzyme overall purification profile from $\mathrm{S}$. canarius culture was summarized in (Table 1). The crude extract contained 23.0 $\mathrm{mg}$ of protein and showed a total glutaminase activity 170 units with specific activity of $7.4 \mathrm{U} / \mathrm{mg}$ protein. At all purification steps, the specific activity increased compared to crude enzyme. The maximum specific activity 132.2 $\mathrm{U} / \mathrm{mg}$ protein with a yield of $28 \%$ was attained after Sephadex G100 purification. The partial purified was increased more than 17 fold compared with crude enzyme. These results were in similarity with that reviewed by Mohana Priya et al. (2011). Also, Kumar et al. (2012) stated that Bacillus sp. LKG-01 (MTCC 10401) L-glutaminase activity was purified 49-fold from cell-free extract with $25 \%$ recovery with specific activity $584.2 \mathrm{U} / \mathrm{mg}$ protein after gel filtration.

TABLE 1. Summary of purification steps of Streptomyces canarius L- glutaminase.

\begin{tabular}{|l|c|c|c|c|c|}
\hline \multicolumn{1}{|c|}{ Purification steps } & $\begin{array}{c}\text { Enzyme } \\
\text { activity } \\
(\mathbf{U})\end{array}$ & $\begin{array}{c}\text { Total } \\
\text { sprotein } \\
(\mathbf{m g})\end{array}$ & $\begin{array}{c}\text { Specific } \\
\text { activity (U/mg } \\
\text { protein) }\end{array}$ & $\begin{array}{c}\text { Purificatio } \\
\text { n fold }\end{array}$ & $\begin{array}{c}\text { Yield } \\
(\%)\end{array}$ \\
\hline Crude extract & 170 & 23 & 7.4 & 1 & 100 \\
\hline 70\% Amm.Sulph.ppt & 145 & 17 & 8.5 & 1.2 & 85 \\
\hline Sephadex G100 & 95 & 0.77 & 123.4 & 16.7 & 56 \\
\hline Sephadex G50 & 47.6 & 0.36 & 132.2 & 17.9 & 28 \\
\hline
\end{tabular}

Determination of molecular weight for enzyme

The molecular homogeneity of the purified enzyme from fermentation condition, as well as their purification steps were evaluated by SDS-PAGE. Single band of $44 \mathrm{kDa}$ was appeared after final purification step (Column

Egypt. J. Bot., 54, No. 1 (2014) 
Sephadex $\mathrm{G}_{100}$ ) for the enzyme from S. canarius (Fig. 1). Similarly, the molecular mass of the native enzyme from Stenotrophomonas maltophilia NYW81 was estimated to be $41 \mathrm{kDa}$ by gel filtration (Wakayama et al., 2005).

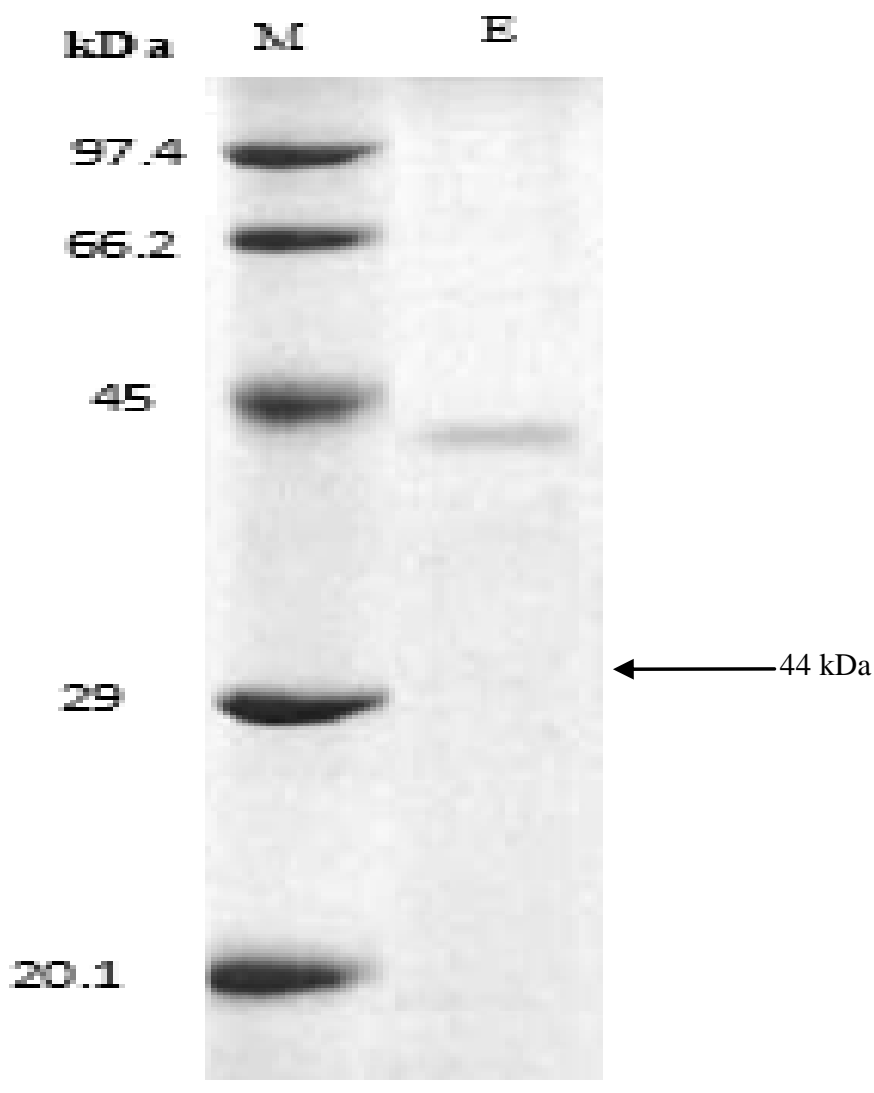

Fig. 1. SDS- PAGE of purified L-glutaminase from $S$. canarius. Lane M (marker protein), Lane $E$, the purified enzyme.

Biochemical properties of the purified L-glutaminase

Optimal $\mathrm{pH}$ and $\mathrm{pH}$ stability

The enzyme maintained its activity over a range of $\mathrm{pH} 5.0-9$ with optimum at pH 8.0 (Fig. 2 A). The activity significantly decreased at both low and high pH values. The $\mathrm{pH}$ stability of the enzyme also showed a similar trend, the enzyme was stable at wide range $\mathrm{pH}$ 5.0-11.0 with being most stable at $\mathrm{pH}$ 7.0-9.0. Practically, at acidic $\mathrm{pH}$ values a higher rate of enzyme inactivation was appeared, comparing to alkaline side, assuming the enzyme basic identity. The negative effect on enzyme activity at lower and higher $\mathrm{pH}$ values, suggesting the effect on ionization state of enzyme, modifying the enzyme surface charge, 
dissociation of subunits/ coenzyme, consequently disrupt its binding with substrate. Consistently, the activity of L-glutaminase from $S$. canarius showed alkaline optimum $\mathrm{pH} 7-8$, this neutral $\mathrm{pH}$ stability of enzyme, being a favored criterion for enzyme action in vivo. Similarly, Streptomyces gulbargensis Lasparaginase was more stable at the alkaline $\mathrm{pH}$ than at the acidic one (Amena et al., 2010 and Kumar et al., 2012).

\section{Optimal temperature and thermal stability}

The optimum temperature for the enzyme activity was determined by incubation of the reaction mixture at various degrees $\left(25-50^{\circ} \mathrm{C}\right)$ using Lglutamine as substrate in $0.1 \mathrm{M}$ potassium phosphate buffer $(\mathrm{pH} 8.0)$. The highest enzyme specific activity $(53.3 \mathrm{U} / \mathrm{mg})$ was obtained at $40^{\circ} \mathrm{C}$. Above and below this temperature the enzyme activity decreased (Fig. 2 B). Regarding to thermal stability the enzyme had a catalytically thermal stability below $60{ }^{\circ} \mathrm{C}$, with a slightly decreasing in its activity at $70^{\circ} \mathrm{C}$ for $20 \mathrm{~min}$ and completely lost its activity at $80^{\circ} \mathrm{C}$ (Fig. $2 \mathrm{C}$ ). The enzyme half-life times $\left(\mathrm{T}_{1 / 2}\right)$ was $45.7,38.8,29.3$ and $17.3 \mathrm{~min}$ at $50,60,70$ and $80^{\circ} \mathrm{C}$, respectively. Also, the Tm of enzyme was $57.5^{\circ} \mathrm{C}$, assuming the retaining of about $50 \%$ of its initial activity by heating for $60 \mathrm{~min}$ (Fig. 2 D). Theoretically, thermal inactivation rates (Kr) are 0.0184, $0.0227,0.0544$ and $0.0449 \mathrm{~S}-1$ at $50,60,70$ and $80^{\circ} \mathrm{C}$ respectively, suggesting the dissociation of co-enzyme or denaturation of subunits by heating per unit time. These results were in consistent with those reported for Amena et al. (2010) and Kumar et al. (2012).

\section{Salt tolerance of $S$. canarius L-glutaminase}

The results represented in (Fig. 2 E) showed that, tolerance in glutaminase activity was observed by increasing the $\mathrm{NaCl}$ concentration upto $25 \%$. Marine actinomycete isolates were tolerated high salt conc. (Krishnakumar et al., 2011 and Kumar et al., 2012).

Substrate specificity and kinetic properties of S. canarius L-glutaminase

The kinetic parameters for L-glutaminase towards substrates were determined from Michaelis-Mentel constant and the Lineweaver-Burk Plot (Fig. 2 F and Table 2). The enzyme had relative high affinity and catalytic activity for Lglutamine (Km $2.4 \mathrm{mM}$, Vmax $28.1 \mathrm{U} / \mathrm{mg} / \mathrm{min})$, followed by L- asparagine (Km $2.6 \mathrm{mM}, \mathrm{V} \max 25.5 \mathrm{U} / \mathrm{mg} / \mathrm{min})$ and low affinity to L-aspartic acid (Km $6.2 \mathrm{mM}$, Vmax $9.5 \mathrm{U} / \mathrm{mg} / \mathrm{min}$ ). Also, the highest catalytic efficiency (Kcat turnover number) for the enzyme was assessed for L-glutamine $\left(0.64 \times 10^{-3} \mathrm{~s}-1\right)$ followed by L-asparagine $\left(0.58 \times 10^{-3} \mathrm{~s}-1\right)$ and L-aspartic acid $\left(0.22 \times 10^{-3} \mathrm{~s}-1\right)$. The high affinity of $S$. canarius L-glutaminase to L-glutamine as substrate was detected previously by Senthil-Kumar and Selvam (2011) and Kumar et al. (2012) for Streptomyces radiopugnans MS1 and Pseudomonas sp.BTMS-51, respectively. Also, the small $\mathrm{Km}(2.4 \mathrm{mmol})$ of the tested $S$. canarius L-glutaminase indicated high affinity of the enzyme to glutamine meaning that the rate will approach Vmax more quickly (Lehninger et al., 2005). 


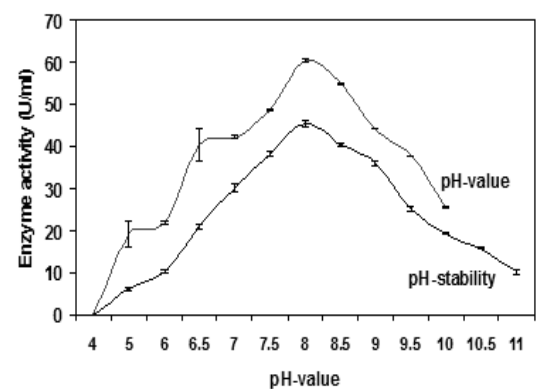

(A)

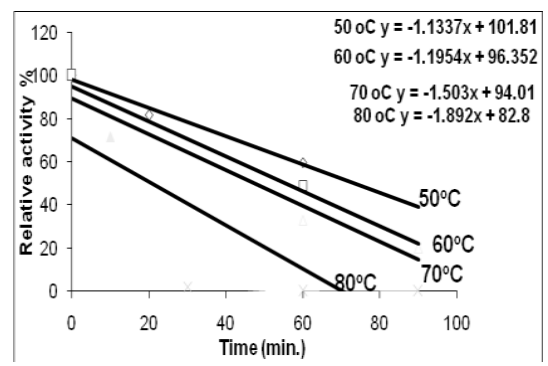

(C)

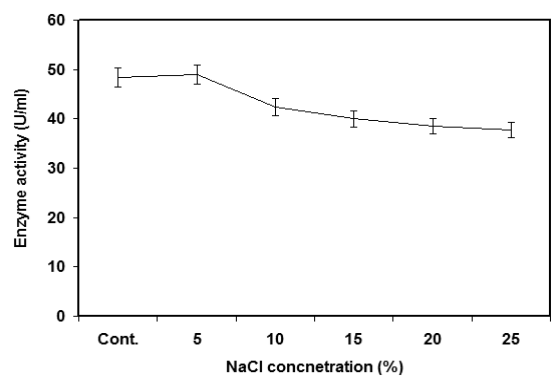

(E)

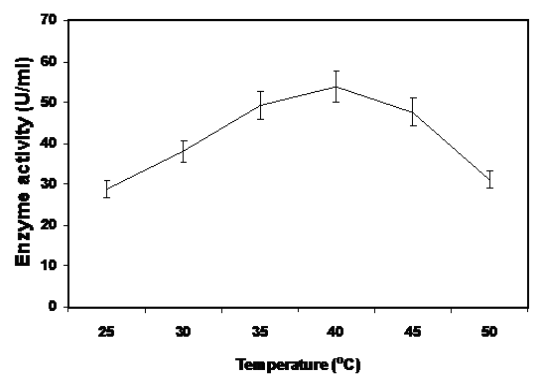

(B)

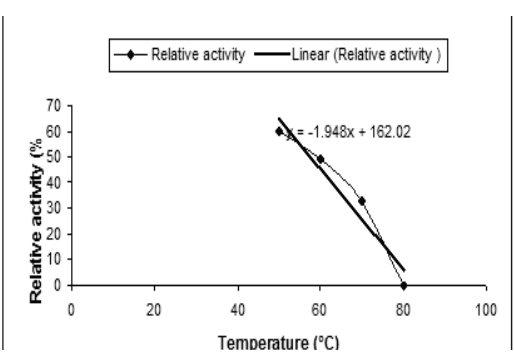

(D)

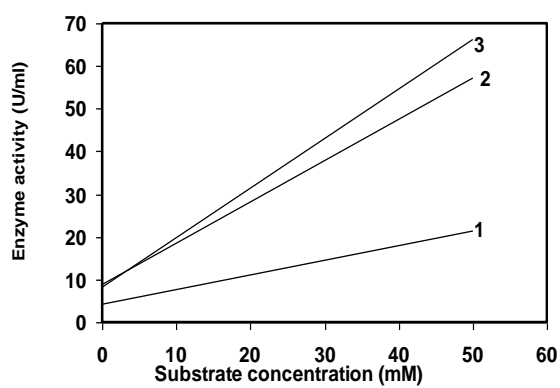

(F)

Fig. 2. Characterization of $S$. canarius L-glutaminase.

(A) $\mathrm{pH}$ value and $\mathrm{pH}$ stability profile. The enzyme was preincubated for $2 \mathrm{hr}$ at various pHs (4.0 -11.0), then measuring the residual deaminating activity; (B) The optimal temperature for activity was assessed by measuring the enzyme activity at different temperatures between 25 and $50^{\circ} \mathrm{C}$; (C) Thermal stability profile. After incubation of enzyme in different temperature $\left(50-80^{\circ} \mathrm{C}\right)$ at various periods $(10-90$ $\mathrm{min}$ ), the residual activity was determined by the standard assay method; (D) Thermal inactivation profile. $\mathrm{Tm}$ is temperature degree at which the enzyme retains half of its initial activity at $60 \mathrm{~min}$. (E) Different $\mathrm{NaCl}$ concentrations from $0-25 \%$; (F) Enzyme specificity towards substrates, (1) L- aspartic acid y $=0.344 \mathrm{x}$ +6.894 ; (2) L-asparagine $y=0.975 x+15.29 ;$; (3) L-glutamine $y=1.081 x+16.66$. 
TABLE 2. Kinetics of $S$. canarius L- glutaminase.

\begin{tabular}{|l|c|c|c|}
\hline Substrates $(\mathbf{m M})$ & $\mathbf{K m}\left(\mathbf{m m o l}{ }^{-1}\right)$ & $\mathbf{V m a x}\left(\mathbf{U ~ m g}^{-\mathbf{1}}\right.$ protein $\left.\mathbf{m i n}^{-\mathbf{1}}\right)$ & Kcat $\left(\mathbf{s}^{-\mathbf{1}}\right)$ \\
\hline L- glutamine & 2.4 & 28.1 & $0.64 \times 10^{-3}$ \\
\hline L- asparagines & 2.6 & 25.5 & $0.58 \times 10^{-3}$ \\
\hline Aspartic acid & 6.2 & 9.5 & $0.22 \times 10^{-3}$ \\
\hline
\end{tabular}

The kinetic parameters were determined by incubation of the enzyme (132.2 U/mg protein) in potassium phosphate buffer $(\mathrm{pH} 8)$ with various concentrations of substrate $(10-100 \mathrm{mM})$ under the standard assay conditions, then measuring the deaminating activity of the enzyme. Maximum velocity (Vmax) was expressed by activity of enzyme in $\mu$ mol of $\mathrm{NH} 3$ compounds formed per minute per mg protein enzyme. $\mathrm{Km}$ is the substrate concentration $(\mathrm{mM})$ at half of maximum velocity. Kcat is the maximum velocity of the enzyme per mol per sec.

\section{Influence of metal ions on L-glutaminase activity}

The impact of various inhibitors and activators on catalytic potency of the enzyme was evaluated by pre incubation of the enzyme with each compound (10mM final conc.) for $30 \mathrm{~min}$ without substrate. Results in (Table 3) showed that among the tested ions, $\mathrm{Ca}^{+2}, \mathrm{Ba}^{+2}, \mathrm{Fe}^{+3}, \mathrm{Zn}^{+2}, \mathrm{Cu}^{+}, \mathrm{Hg}^{+2}$ and $\mathrm{Cd}^{+2}$ decreased significantly the enzyme residual. On the other hand, $\mathrm{Mn}^{+2}, \mathrm{Na}^{+}$and $\mathrm{Co}^{+2}$ were enzyme inducer. These results were in agreement with Senthil-Kumar and Selvam (2011) for Streptomyces radiopugnans MS1 L-asparaginase.

TABLE 3. Effect of inhibitors and activators on L- glutaminase activity.

\begin{tabular}{|c|c|}
\hline Metal ions (5mM) & Relative activity $(\%)$ \\
\hline None (control) & $100.67 a b c \pm 0.15$ \\
\hline $\mathrm{Ca}^{+2}$ & $75.33 \mathrm{~cd} \pm 0.76$ \\
\hline $\mathrm{Na}^{+2}$ & $105.00 \mathrm{ab} \pm 0.50$ \\
\hline $\mathrm{Ba}^{+2}$ & $56.70 \mathrm{~d} \pm 5.29$ \\
\hline $\mathrm{Mg}^{+2}$ & $81.33 \mathrm{bc} \pm 60.48$ \\
\hline $\mathrm{Hg}^{+2}$ & $20.00 \mathrm{e} \pm 0.50$ \\
\hline $\mathrm{Co}^{+2}$ & $122.00 \mathrm{a} \pm 0.50$ \\
\hline $\mathrm{Fe}^{+3}$ & $53.00 \mathrm{~d} \pm 0.87$ \\
\hline $\mathrm{Mn}^{+2}$ & $125.00 \mathrm{a} \pm 0.50$ \\
\hline $\mathrm{Cu}^{+2}$ & $50.00 \mathrm{~d} \pm 0.50$ \\
\hline $\mathrm{Zn}^{+2}$ & $87.00 \mathrm{bc} \pm 0.92$ \\
\hline $\mathrm{Cd}^{+2}$ & $17.00 \mathrm{e} \pm 0.50$ \\
\hline 1.s.d & 27.49 \\
\hline $\mathrm{F}$ & 12.669 \\
\hline
\end{tabular}

The enzyme activity was determined in the absence and presence of different ions at concentration 10 $\mathrm{mM}$ after a $30 \mathrm{~min}$ exposure to each ion. The relative activity was expressed as the percentage ratio of the activity of the enzyme incubated with the effectors to that of the untreated enzyme. 
Cytotoxicity effect of L-glutaminase enzyme

The cytotoxicity effect of purified S. canarius L-glutaminase was explored based on the hematological and blood chemistry pictures for the New Zealand rabbits (Table 4). The rabbits were injected by $1 \mathrm{ml}$ of three successive doses of enzyme (132.2 U/mg protein) during two weeks. From the biochemical profiles, there is no obvious negative effect on liver, renal functions, glucose, lipids and other electrolytes, with slight inducing effect on the activity of ALT, AST and level of Random Sugar Glucose. As well as, rabbits were alive along the experimented periods. Depending on these results, the enzyme had relatively no negative effect on liver functions, where AST and ALT was the most potential indicator for liver dysfunction (Pratt and Kaplan 2000).

Also, the cellular toxicity of the purified S. canarius L-glutaminase was evaluated by estimation of the degree of platelets aggregations and hemolytic activity as described by Wei et al. (2007). All the hematological parameters (Table 4) were in normal range along the experimented period, however, the red blood cells, hemoglobin, white blood cells and the platelets slightly decreased after 10 days of L-glutaminase injection, comparing to control (before injection). The enzyme displayed no hemolytic activity to human blood (Plate 1). Platelet aggregation and hemolytic activity are the most relevant biochemical assays (Pratt and Kaplan 2000). The lack of ability to aggregate human platelets and lyses of human RBCs are unique supportive criteria from therapeutic point of view. Similar results approved the non cytotoxicity of microbial glutaminase (Baskerville et al.,1980).

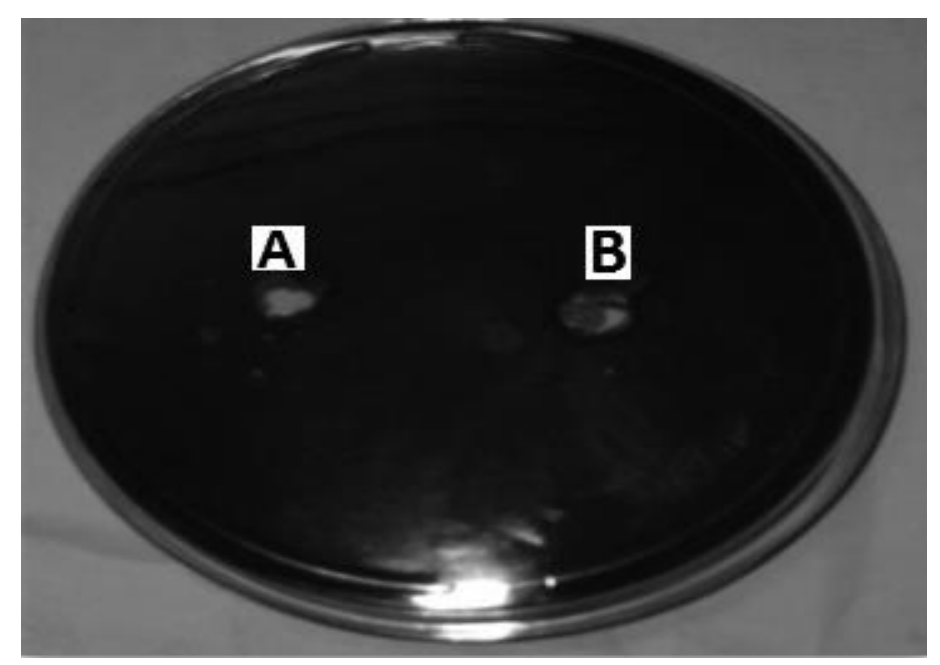

Plate 1. Hemolytic activity of Strepromyces canarius L- glutaminase, $100 \mu \mathrm{l}$ of purified enzyme (A) and $200 \mu \mathrm{l}$ purified enzyme (B). 


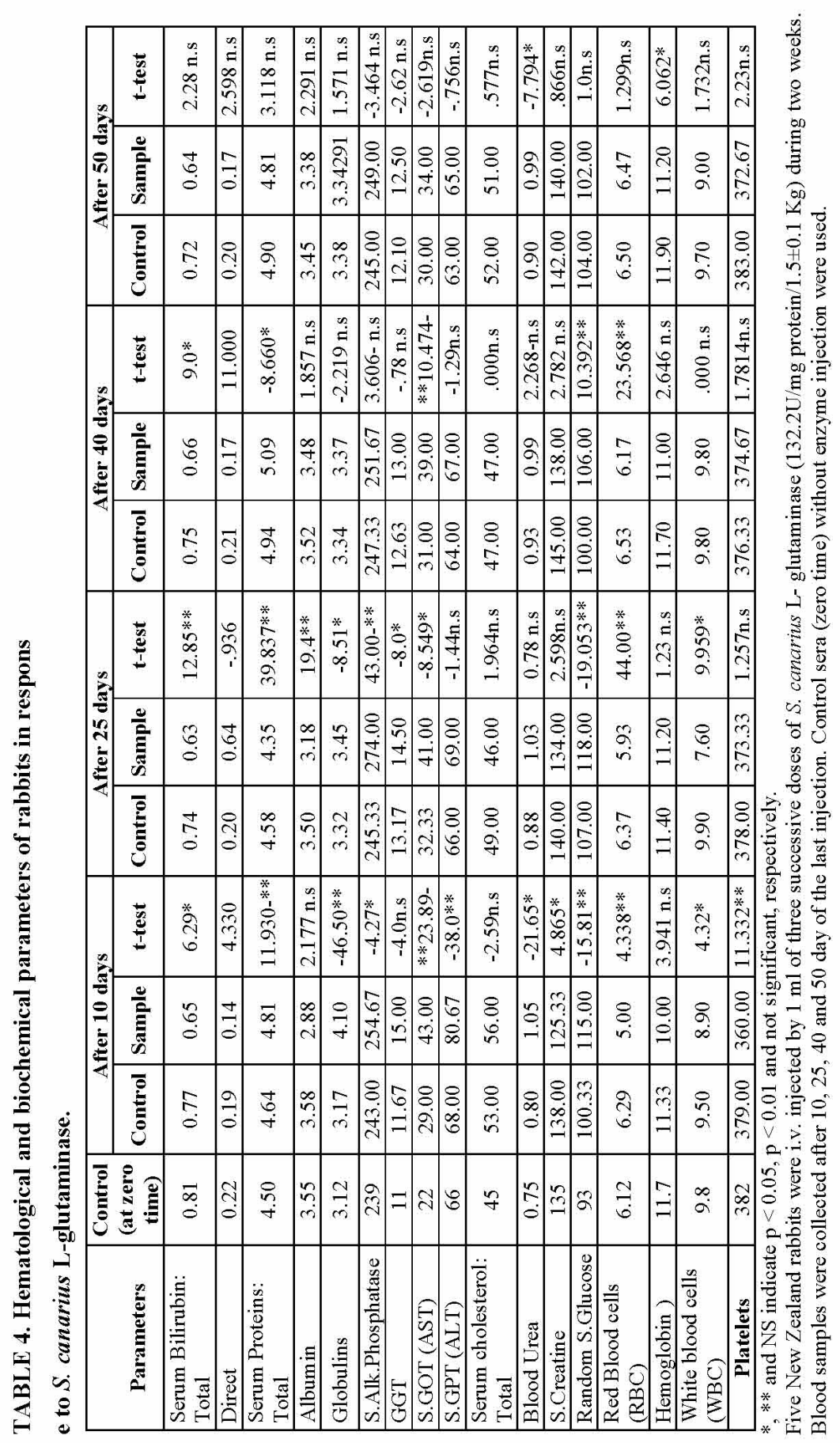

Egypt. J. Bot., 54, No. 1 (2014) 


\section{Histological studies on the effect of enzyme induced in rabbits}

For histological studies, small portion of liver and kidney of treated and non treated rabbits after 50 days of the last injection were investigated. From photomicrograph of renal and liver tissues (Fig. 3 and 4), there is obvious slight effect on the tested tissues, comparing with the negative controls. Photomicrograph of renal tissue of negative control showing normal glomeruli surrounded by normal renal tubules lined cubical epithelial cells, whereas in treated tissue showed round distal convoluted tubules lined by cubical epithelium and longitudinal collecting duct lined by columnar epithelium (Fig. 3). Also, photomicrograph of tested liver tissue showing variable sized central veins surrounded by cords and rows of hepatocytes, comparing with negative control (Fig. 4). These results were in similarity with that obtained by Baskerville et al. (1980) and Roy and Maity (2007).

\section{Anticancer efficiency In Vitro}

Using MTT assay in the present investigation, the effect of the purified enzyme on the growth of Hep-G2, MCF7, HCT-116, HeLa and RAW 264.7 cells were studied after $48 \mathrm{hr}$ of incubation. As shown in (Fig. 5), the tested enzyme had a high efficiency against Hep-G2 cell $\left(\mathrm{IC}_{50}, 6.8 \mu \mathrm{g} / \mathrm{ml}\right)$ and HeLa cells $\left(\mathrm{IC}_{50}\right.$, $8.3 \mu \mathrm{g} / \mathrm{ml}$ ), while the growth of MCF-7 cells was not affected by the treatment. On the other hand, the treatment of HCT-116 and RAW 264.7 cells with the tested enzyme indicated that there was a moderate cytotoxic effect as concluded from their high $\mathrm{IC}_{50}$ calculated values: $64.7 \mu \mathrm{g} / \mathrm{ml}$ and $59.3 \mu \mathrm{g} / \mathrm{ml}$, respectively, compared with the known anticancer drug paclitaxel, which its $\mathrm{IC}_{50}$ values for these cell lines ranged from 0.5-1.2 $\mu \mathrm{g} / \mathrm{ml}$. Similarly, Devi and Azmi (2012) showed that the purified L-asparaginase from Erwinia carotovora MTCC 1428 used for killing of Hep-2C cell line. Also, E. carotovora MTCC 1428 asparaginase was showed better in vitro toxicity on Hep-2C cell lines (84\% survival) in comparison to commercial L-asparaginase preparation $(90 \%$ survival) obtained from E. coli. Meanwhile, Nathiya et al. (2012) indicated a crucial role of Aspergillus flavus KUGF009 L-glutaminase in breast cancer (MCF7). Moreover, Roberts et al. (1970) found that L-glutaminase from Pseudomonas sp. 7A is administered to inhibit HIV replication in infected cells. The enzyme brings about inhibition of tumor (melanoma) and DNA biosynthesis in affected cells. Glutaminase and asparaginase enzymes have produced prolonged remissions of certain experiment tumors (Wriston and Yellin, 1973). During treatment, plasma glutamine and asparagines are depleted. The degree of amino acid depletion depends on the kinetic properties of the enzymes, its biological half life in the animal and the rate of input of the amino acid into circulation (Wriston and Yellin, 1973).

In conclusion, $S$. canarius (KC460654) had remarkable capacity to produce L- glutaminase. The purified enzyme showed a unique specificity to glutamine, broad $\mathrm{pH}$ stability, and high thermal stability. Also, the purified enzyme is being promising candidate for application as antitumor agent in the future work.

Acknowledgement: The author would like to thank Dr. Akmal Sakr for collecting of samples. 


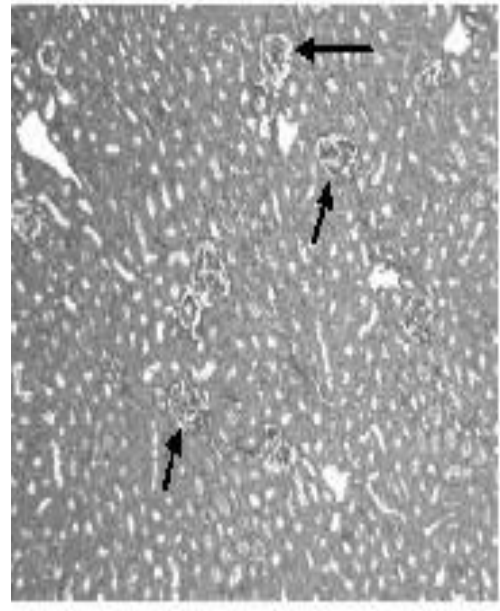

A. Hematoxylin and Eosin $(\mathrm{H} \& \mathrm{E}) \mathrm{X} 150$

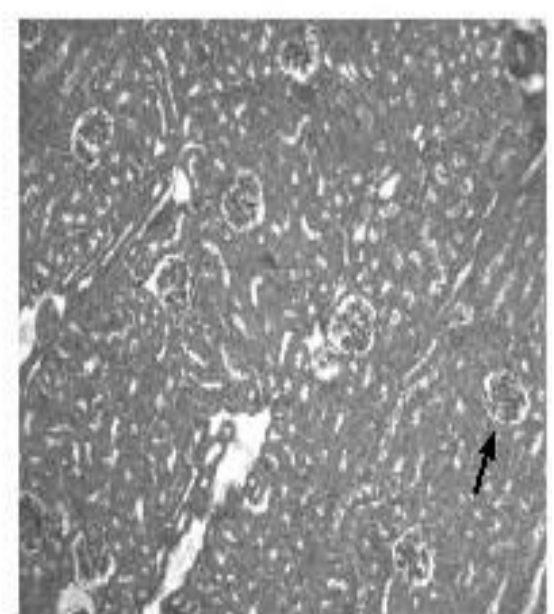

A. H \& E X 200

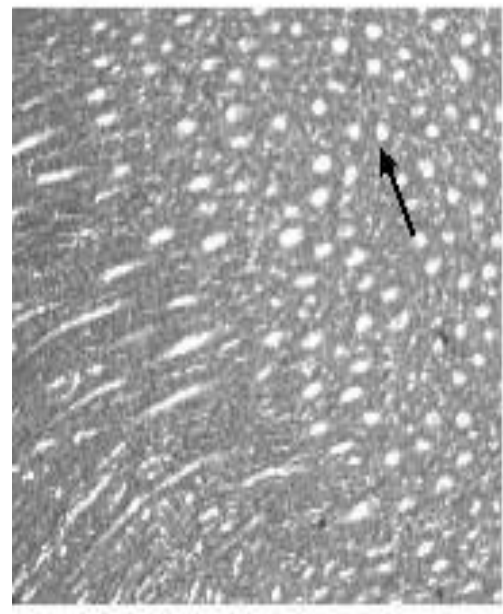

B. $\mathrm{H} \& \mathrm{E}$ X 150

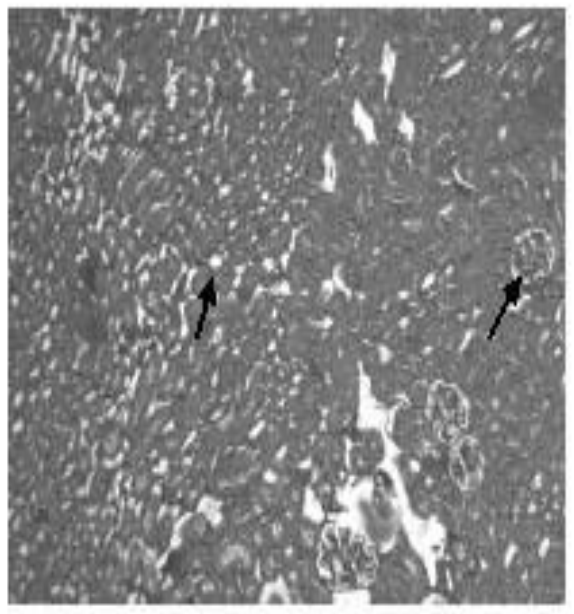

B. H \& E X 200

Fig. 3. Photomicrograph (at Hematoxylin and Eosin X 150 and X200) of renal tissue of (A) negative control showing normal glomeruli ( $($ ) surrounded by normal renal tubules lined cubical epithelial cells. (B) treated yith $S$. canarius $L$ glutaminase showing round distal convoluted tubules (T) lined by cubical epithelium and longitudinal collecting duct lined by columnar epithelium. 


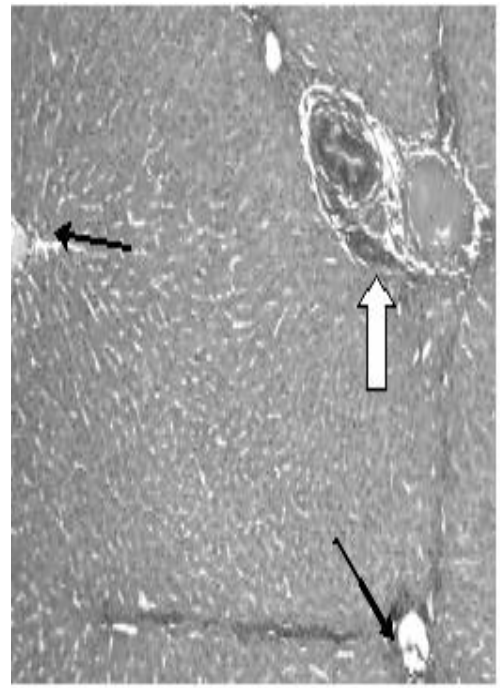

(C) H\&EX150

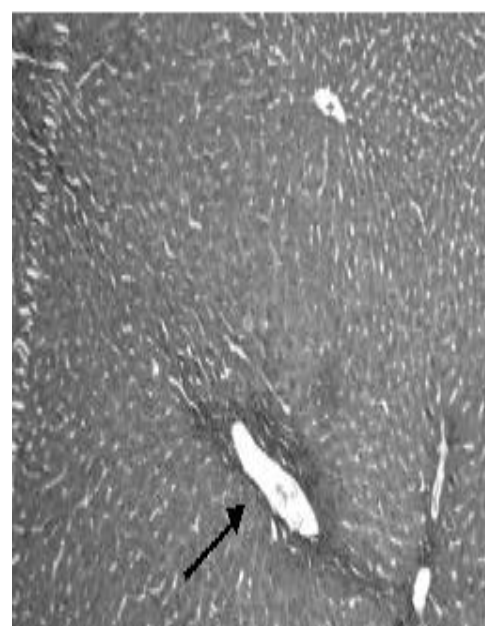

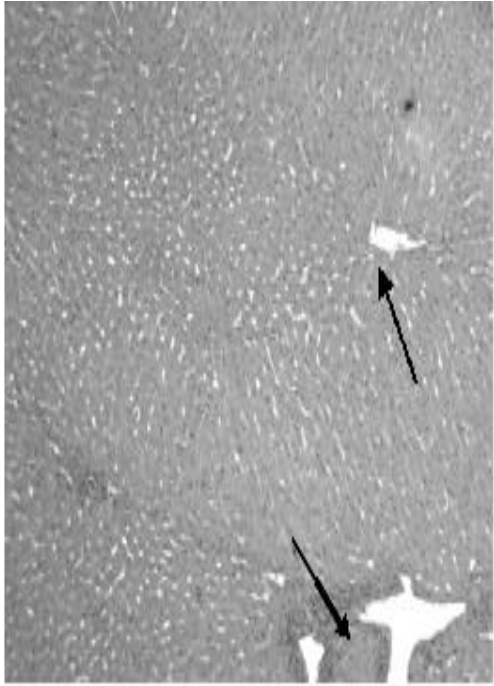

(C) H\&EX 200

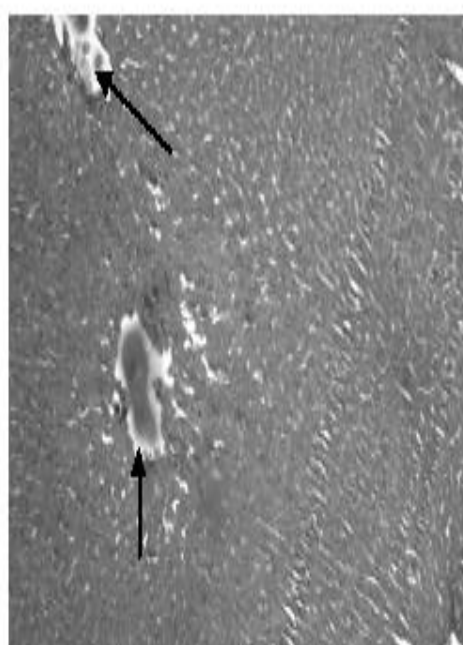

Fig. 4. Photomicrograph (at H \& E X 150 and X200) of liver tissue of ( C ) negative control showing normal architecture formed of central vein $(\widehat{T})$ and portal tract $(\uparrow)$ surrounded by cords and rows of normal hepatocytes. (D) Treated with $S$. canarius L-glutaminase showing variable sized central veins ( surrounded by cords and rows of hepatocytes. 


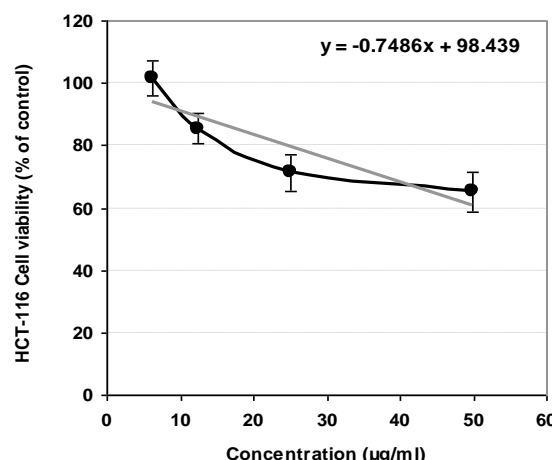

(A)

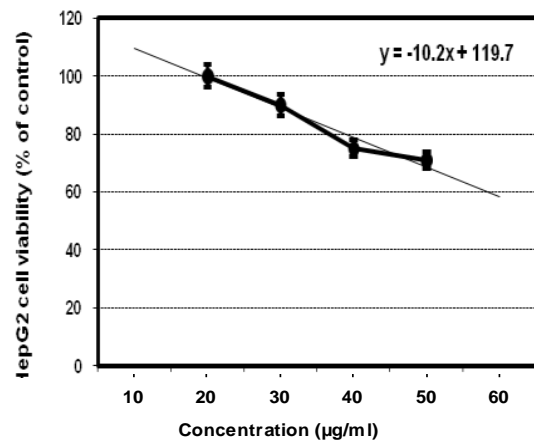

(C)

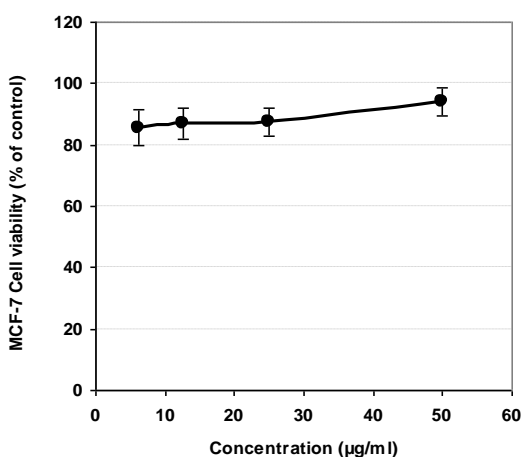

(B)

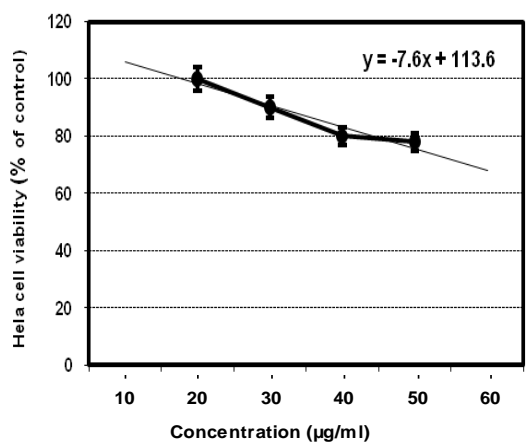

(D)

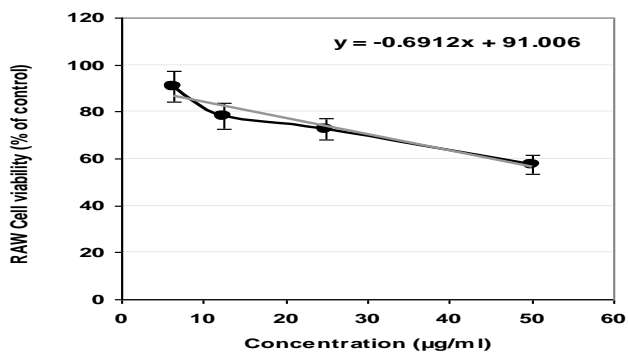

(E)

Fig. 5. Cytotoxic effect of $S$. canarius $L$-glutaminase on tumor cell lines using MTT assay (n=4), HCT-116 (A), MCF-7 (B), HepG2 (C), HeLa (D) and RAW 264.7 (E). Cells exposed to different concentrations of the drug for 48 hours. All data are expressed as the mean value of cell viability ( $\%$ of control $) \pm$ S.E.S.

Egypt. J. Bot., 54, No. 1 (2014) 


\section{References}

Altschul, S.F., Madden, T.L., Schäffer, A.A., Zhang, J., Zhang, Z., Miller, W. and Lipman, D.J. (1997) Gapped BLAST and PSI-BLAST: a new generation of protein database search programs. Nucleic Acids Res., 17, 389-402.

Amena, S., Vishalakshi, N., Prabhakar, M., Dayanand, A. and Lingappa, K. (2010) Production, purification and characterization of L-aparaginase from Streptomyces gulbargensis. Braz J. Microbiol., 41, 1517-8382.

Balagurunathan, R. and Subramanian, A. (1993) Studies on marine Streptomyces nigrifaciens (P9) I. Taxonomy and standardization of antibiotic production. Ciencias Marinas, 19, 435-443.

Balagurunathan, R., Radhakrishnan, M. and Somasundaram, S.R. (2010) Lglutaminase sediments - selective isolation, semi Quantitative assay and characterization of potential strain. Australian J. of Basic and Appli Sci., 4, 698-705.

Baskerville, A., Hambleton, P. and Benbough, J.E. (1980) Pathological features of glutaminase toxicity. Br.J. Exp. Pathol., 61, 132-138.

Birt, J.H. (1967) International Committee for Standardization in Hematology. 13 (Suppl.) 716, 6-18.

Borek, D., Michalska, K., Brzezinski, K., Kisiel, A., Podkowinski, J., Bonthron, D.T., Krowarsch, D., Otlewski, J. and Jaskolski, M. (2004) Expression, purification and catalytic activity of Lupinus luteus asparagines $\beta$-amidohydrolase and its Escherichia coli homolog. Eur, J. Biochem., 271, 3215-3226.

Chantawannakul, P., Yoshimune, K., Shirakihara, Y., Shiratori, A., Wakayama, M. and Moriguchi (2003) Crystallization and preliminary X-rays crystallographic studies of salt-tolerant glutaminases from Micrococcus luteus K-3. Acta Crystallogr, 59, 566 568 .

Dang , C.V. (2010) Glutaminolysis: supplying carbon or nitrogen. Cell Cycle 19(9), 3884-6.

Devi, S, Azmi, W. (2012) One step purification of glutaminase free L- asparaginase from Erwinia carotovora with anticancerous from activity. Int. J. Life Sci. pharma Res., 2, 2250-0480.

Dura, M.A., Flores, M. and Toldra, F. (2002) Purification and characterization of Lglutaminase from Debaryomyces spp. Int. J. Food. Microbiol., 76,117-126.

Garrity,G.M. (2002) “Bergey's Manual of Systematic Bacteriology”. Springer-Verlag, New York.

Hansen, M.B., Nielsen, S.E. and Berg, K. (1989) Re-examination and further development of a precise and rapid dye method for measuring cell growth/cell kill. $J$. Immunol. Methods, 119, 203-10. 
Iyer, P. and Singhal, R.S. (2008) Production of glutaminase (E.C.3.2.1.5) from Zygosaccharomyces rouxii: Statistical optimization using response surface methodology. Bioresour Technol., 99, 4300-4307.

Kämpfer, P. (2006) "The Prokaryotes. A Handbook on the Biology of Bacteria". Vol. 3, in: M. Dworkin, S. Falkow, E. Rosenberg, K.-H. Schleifer, E. Stackebrandt (Ed.), The family Streptomycetaceae. Part I, Taxonomy, $3^{\text {rd }}$ ed., Springer-Verlag, Berlin. pp. 538-604.

Kannan, R.R. and Vincent, S.G.P. (2011) Molecular characterization of antagonistic Streptomyces isolated from a mangrove swamp. Asian. J. Biotechnol., 3, 237-245.

Kieser, T., Bibb, M.J., Buttner, M.J., Chater, K.F. and Hopwood, D.A. (2000) “General Introduction to Actinomycete Biology”. In: Practical Streptomyces genetics. pp. 1-42. The John Innes Foundation, Norwich, UK.

Krishnakumar, S., Alexis, R. and Ravikumar, S. (2011) Extracellular production of LGlutaminase by marine alkalophilic Streptomyces $s p$-SBU1 isolated from Cape Comorin coast. IJMS 40,717-721.

Kumar, L., Singh, B., Adhikari, D.K., Mukherjee, J. and Ghosh, D. (2012) A temperature and salt-tolerant L-glutaminase from gangotri region of uttarakhand himalaya: enzyme purification and characterization. Appl. Biochem. Biotechnol., 166,1723-35.

Kyoko, K., Hrroaki, N., An Y., Jiro, K. and Katsuhiko, K. (2004) Glutamninase, its gene and a method of producing it. U.S. Patent. Pat. No. 6830905 B2.

Laemmli, U.K. (1970) Cleavage of structural proteins during the assembly of the head of bacteriophage T4. Nature (London), 227, 680-685.

Lazarus, P. and Panasci, L.C. (1986) Characterization of L-theronine and Lglutamine transport in murine P388 leukemia cells in vitro. Presence of an N-like amino acid transport system. Biochem. Biophys. Acta, 856, 488-495.

Lehninger, A.L., Nelson, D.L. and Cox, M.M. (2005) "Lehninger Principles of Biochemistry”. $4^{\text {th }}$ ed., New York: W.H. Freeman and Company. 194-196.

Lowery, O.H., Rosebrouph, A.L., Farr, N.J. and Randall, R.J. (1951) Protein measurement with folin- phenol reagent. J. Biol. Chem., 193, 265-275.

Masayukr, M., Katsuya. G., Kiyoshi, G., Motoaki, S. and Taishin, K. et al. (2007) 'Thermostable glutaminase and thermostable glutaminase gene. U.S. Patent No: U.S. 7186540 B2.

Mohana, Priya, P., Radhakrishnan, M. and Balagurunathan, R. (2011) Production and optimization of L-asparaginase from Streptomyces sp (TA22) isolated from Western Ghats, India. J. Chem. Pharm. Res., 3, 618-62.

Nagendra Prabhu, G. (1997) L-glutaminase production by marine Vibrio costicola under solid state fermentation. Ph.D. Thesis, Cochin University of Science \& Technology, Cochin, India.

Egypt. J. Bot., 54, No. 1 (2014) 
Nathiya, K., Nath, S.S., Angayarkanni, J. and Palaniswamy, M. (2012) In vitro cytotoxicity of L- glutaminase against MCF-7 cell line. Asian J. of Pharm and Clinical Res., 5, 0974-2441.

Pratt, D.S. and Kaplan, M.M. (2000) Evaluation of abnormal liver enzyme results in asymptomatic patients. N. Engl. J. Med., 342,1266-1271.

Ranjekar, M.K. and Sridhar, K.R. (2002) Occurrence and extracellular enzymatic potential of actinomycetes of a Thermal spring, Southern India. Asian J. Microbiol. Biotechnol. Env. Sci., 4, 59-64.

Reitman, S. and Frankel, S. (1957) A colorimetric method for the determination of serum glutamic oxalacetic and glutamic pyruvic transaminases. Amer. J. Clin. Pathol, 28, 56-63.

Robert, J., Allister, J.W., Sethuraman, N. and Freeman, A.G. (2001) Genetically engineered glutaminase and its use in antiviral and anticancer therapy. U.S. Patent, No. 6312939.

Roberts, J., Holcenberg, J.S. and Dolowy, W.C. (1970) Nature, 227,1136.

Roy, S. and Maity, P. (2007) Modulation of Metastatic Potential of B16F10 Melanoma Cells by Acivicin: Synergistic Action of Glutaminase and Potentiation of Cisplatin Cytotoxicity. Asian Pacific Journal of Cancer Prevention, 8, 301-306.

Sabu, A. (2003) Sources, properties and applications of microbial therapeutic enzymes Ind. J. Biotechnol., 2, 334-341.

Sabu, A., Nampoothiri, K.M. and Pondey, A. (2005) L-Glutaminase as a therapeutic enzyme of microbial origin. In: "Methods in Biotechnology: Microbial Enzymes and Biotransformations”. Baredo, J.L., (Ed.), Humana Press Inc, Totowa. NJ. pp: 75-90.

Salvatore, D. and Reagle, D. (2001) "Theory and Problems of Statistics and Econometrics". $2^{\text {nd }}$ ed., McGraw Hill, New York.

Senthil-Kumar, M. and Selvam, K. (2011) Isolation and Purification of High Efficiency L-asparaginase by Quantitative Preparative Continuous-elution SDS PAGE Electrophoresis. J. Microbial. Biochem. Technol., 3, 073-083.

Tanaka, S., Robinson, E.A., Appella, E., Miller, M., Ammon, H.L., Roberts, I., Weber, L.T. and Wolodawer, A. (1988) Structures of Amidohydrolases. Aminoacid sequence of a glutaminase- asparaginase from Acinetobacter glutaminasificans and preliminary crystallographic data for an asparaginase from Erwinia crysanthemi. J. of Biological. Chem., 263(18), $8583-8591$.

Tay, S.T., Devi, S., Puthcheary, S.D. and Kautner, I.M. (1995) Detection of haemolytic activity of Campylobacters by agarose haemolysis and microplate assay. J. Med. Microbiol., 42,175-180.

Wakayama, M., Yamagata, T., Kamemura, A., Bootim, N., Yano, S., Tachiki, T., Yoshimune, K. and Moriguchi, M. (2005) Characterization of salt-tolerant 
glutaminase from Stenotrophomonas maltophilla NYW-81 and its application in Japanese soy sauce fermentation. J. Ind. Microbiol. Biotechnol., 32, 383-390.

Warrell, D.A., Looareesuman, S., Warrell, M.J., Kasemsarin, P., Inteprasert, R., Bunnag, D. and Haritinasuta, T. (1982) Dexamethasone proves deleterious in cerebral malaria: a double blind trial in 100 comatose patients. New England J. of Medicine, 306-313.

Wei, X.L., Wei, J.F., Li, T., Qiao, L.Y., Liu, Y.L., Huang, T. and He, S.H. (2007) Purification, characterization and potent lung lesion activity of an L-amino acid oxidase from Agkistrodon blomhoffii ussurensis snake venom. Toxicon, 50, 11261139.

Whitaker, J.R. (1972) “In: Principles of Enzymology for Food Sciences". Enzyme inhibitors pp. 255-282 New York. Marcel Dekker.

Wriston, J.C. and Yellin, T.O. (1973) L-asparaginase: A review. Advan. Enzymol., 39, 185-248.

(Received 29/10/2013;

accepted $17 / 12 / 2013)$ 


\title{
تتقية وتوصيف انزيم ل الجلوتاميناز المنتج من استربتوميسس كناريس ونثاطه كمضاد للسرطان
}

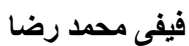 \\ قسم النبات - كلية العلوم - جامعة الزقازيق- الزقازيق- مصر.
}

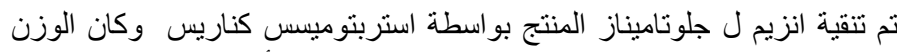

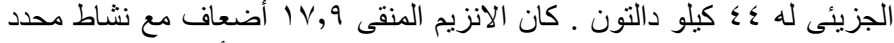

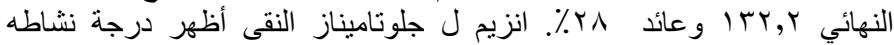

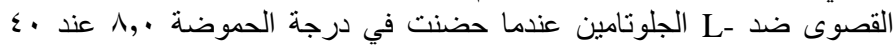

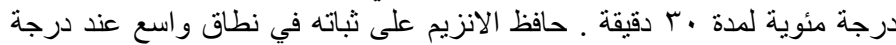

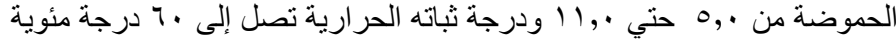

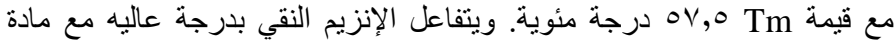

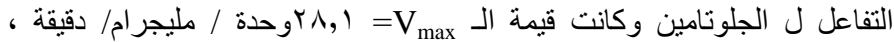

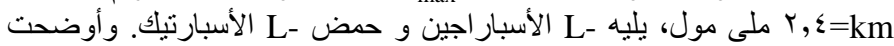

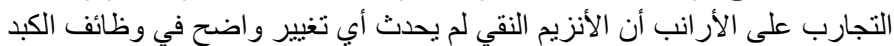

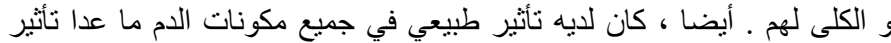

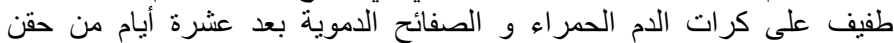

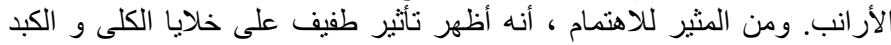

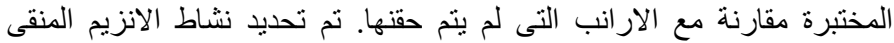

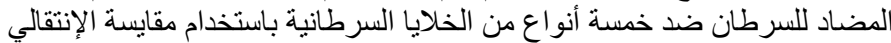

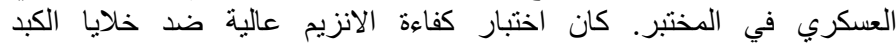

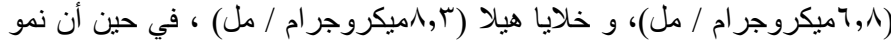

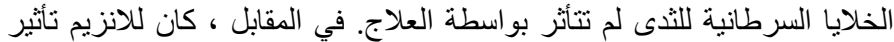

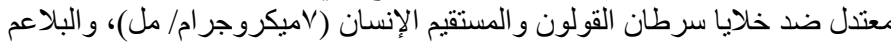

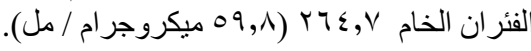

